the federal center. The first level is the competence of the Union and the sphere of the exclusive competence of the Union. The second level is represented by joint and competing competence of the Union and federal entities (the states, the Federal District and municipalities). Exclusive competence of the federal entities can be conditionally included to the third level (and this competence is residual). The authors also give an analysis of paradiplomacy of the four leading Brazilian states; they are Rio de Janeiro, Minas Gerais, São Paulo and Rio Grande do Sul. An important factor in the development of interregional connections of these states is the creation of the special institutional structure. In addition, paradiplomacy of all the abovementioned states is developed in accordance with the provisions of federal and regional documents.

Keywords: paradiplomacy, authorities, areas of responsibility, Union, Federal District, states

НАГУСЛАЕВА Елизавета Альбертовна - магистрант Института стран Азии и Африки Московского государственного университета им. М.В. Ломоносова (125009, Россия, г. Москва, ул. Моховая, 11, cmp. 1; nageliz@icloud.com)

\title{
РЕЛИГИОЗНАЯ ПОЛИТИКА СИ ЦЗИНЬПИНА
}

Аннотация. Статья посвящена изучению религиозной политики Коммунистической партии Китая в период правления Си Цзиньпина с 2013 г. по настоящее время. Приводятся изменения в курсе вероисповедальной политики при действующей власти, даются его специфические характеристики. Автор описывает практическое применение государственных установок по отношению к религии на примере отдельных конфессий и делает вывод о противоречивости осуществляемой властью религиозной политики.

Ключевые слова: религиозная политика, КПК, Китай, Си Цзиньпин

Д ействующим главой Китайской Народной Республики с 2013 г. является Си Цзиньпин. За время его правления во внутренне- и внешнеполитической стратегии Китая обозначились определенные изменения, многие из которых вызвали бурную реакцию мирового сообщества. Среди них масштабная антикоррупционная кампания, централизация власти, обострение территориальных споров в Восточно-Китайском и Южно-Китайском морях, а также принятие ряда законов, идеологически основанных на Документе № 9 2013 г. - циркуляре КПК, отразившем негативное отношение власти к «западным ценностям» (консультационная демократия, «универсальные» ценности, неолиберализм, свобода прессы и т.д.), связанное со стремлением партии усилить контроль над каждым аспектом социальной жизни, способным представлять угрозу режиму [Fu 2015]. Во внутренней политике стремление партии к централизации власти обусловливает тенденцию к ужесточению религиозной политики, росту степени контроля в религиозной сфере жизни общества.

При действующей администрации концептуально новым в риторике партии стал акцент на возросшую роль сети Интернет как канала распространения экстремистской и террористической угроз, который на практике выливается в ведение тщательного контроля за китайским сегментом глобальной сети. В 2016 г. состоялась публикация новых Правил регулирования религиозной деятельности ${ }^{1}$. Новые положения отражают основные идеи политического курса администрации Си Цзиньпина: противостояние иностранному влиянию, необходимость контроля над информационными потоками в глобальной сети, борьба с угрозами терроризма, экстремизма и сепаратизма [杨凯乐 2016].

\footnotetext{
${ }^{1}$ State Council highlights key tasks in 2016 legislative work. - The State Council of the People's Republic of China. URL: http://english.gov.cn/policies/latest_releases/2016/04/13/content_281475326751655.htm (accessed 15.11.2018).
} 
На фоне борьбы партии с распространением зарубежного влияния посредством религии особенно явно выступает стремление государства подчеркнуть значение традиционной культуры Поднебесной. Возрождение китайской традиционной культуры - один из аспектов реализации концепции «китайской мечты» о великом возрождении китайской нации, выдвинутой Си Цзиньпином [Bell 2016: 78; Zheng Wang 2014: 9]. В 2014 г. глава государства озвучил директиву использования привлекательности культуры и ценностей для создания национального имиджа ${ }^{1}$. О внимании КПК к использованию культурных ценностей свидетельствует содержание партийных документов последних лет. В Докладе о работе правительства на открытии 4-й сессии ВСНП 12-го созыва, озвученном в марте 2016 г., было закреплено направление по усовершенствованию работы по охране и использованию культурного наследия ${ }^{2}$.

Идеи и принципы «трех великих учений» - конфуцианства, даосизма и ханьского буддизма - стали активно продвигаться внутри страны и за ее пределами как часть традиционной культуры Китая. По мнению ряда исследователей, руководство КПК и правительства расценивает развитие этих учений как противовес влиянию ислама и христианства [Fenggang Yang 2004: 113].

Власть Китая теперь как никогда благоволит деятельности буддийской сангхи КНР, т.к. в сравнении с остальными конфессиями буддизм наиболее подходит на роль политического инструмента в руках правительства. Это объясняется двумя важнейшими факторами.

Буддизм - самая многочисленная конфессия в Поднебесной из 5 официальных [Hongyi Harry Lai 2003: 43]. Согласно данным исследовательского центра Freedom House, численность верующих в Китае составляет 350 млн чел., из которых буддизм исповедуют от 185 до 250 млн.

Правительство КНР способствует развитию «буддийской дипломатии» Китая на международной арене в рамках «мягкой силы». Ввиду того что большинство буддистов проживают на территории Азиатско-Тихоокеанского региона [Global Religious Landscape], государство применяет буддийскую дипломатию в отношениях с соседними государствами сразу нескольких регионов: ЮгоВосточной Азии, Южной Азии, Дальнего Востока (Россия, Республика Корея, Япония) [Нагуслаева 2017: 167].

Несмотря на номинальную поддержку религиозной свободы граждан, в действительности наблюдается интенсивное ужесточение религиозной политики, осуществляются религиозные преследования в отношении четырех религиозных общин - протестантской, буддистской сангхи Тибета, мусульман Нинся-Хуэйского и Синцзян-Уйгурского автономных районов. Именно ислам, христианство и тибетский буддизм для КПК фактически ассоциируются с угрозой иностранного влияния в отличие от даосизма и китайского буддизма, которые провозглашаются партией элементами традиционной культуры Поднебесной.

Доклад независимой организации Freedom House выделил 4 ключевых аспекта, в которых религиозная политика пятого поколения руководителей отлична от политики предшествующего правительства Ху Цзиньтао.

1. Ужесточение законодательных рамок - принятие новых правовых документов на национальном и местном уровнях; обновление правил в области религии на национальном уровне, местные правила, запрещающие ношение

1 Xi Jinping: China to promote cultural soft power. - China Daily. URL: http://www.chinadaily.com.cn/ china/2014-01/01/content_17208354.htm (accessed 15.11.2018).

2 Доклад о работе правительства на открытии 4-й сессии ВСНП 12-го созыва. - Официальный сайт посольства КНР в РФ. Доступ: http://ru.china-embassy.org/rus/ztbd/2h/t1347563.htm (проверено 15.11.2018). 
религиозной одежды в Синьцзяне, и руководящие принципы, касающиеся случаев самосожжения в Тибете; новые законы о национальной безопасности и борьбе с терроризмом, которые включают положения, которые могут быть использованы для оправдания действий, направленных на подавление мирной религиозной практики.

2. Расширение круга объектов репрессий; применение наказаний к людям, совершающим повседневные акты религиозной деятельности, такие как молитвы в общественных местах, зажигание ладана или просмотр религиозных видео.

3. Повышение степени государственного участия в повседневной религиозной жизни. Наиболее явно это выражается в постоянном размещении представителей власти в местах отправления культа. Кроме того, государство вмешивается в глубоко личные решения верующих, такие как ношение платка, бороды или соблюдение религиозных постов.

4. Адаптация религиозного контроля к новой технологической среде: применение различных способов электронного наблюдения - от видеокамер и беспилотных самолетов до мониторинга онлайн-активности в местах общественного поклонения, часто посещаемых верующими. По мере распространения использования смартфонов власти стали производить блокировку конкретных приложений, преследовать пользователей за распространение и хранение религиозного контента или распространение информации о нарушениях религиозных прав [Cook 2017: 7].

Кроме вышеперечисленных характеристик религиозного контроля действующего правительства, существует еще один ключевой элемент в современной интерпретации свободы вероисповедания граждан: в религиозной политике Китая осуществляется практика религиозного «перевоспитания». Несмотря на обязательство уважать свободу религиозных убеждений, режим выделяет значительные ресурсы в целях влияния на содержание религиозных учений, текстов и сознание отдельных верующих. И в отражении идеологических основ религиозной политики партии эти инициативы часто требуют, чтобы верующие отказывались от основных религиозных принципов своих конфессий или активно их нарушали.

Существует практика привлечения государством религиозных организаций или исследователей к изучению теологических учений с целью выделения элементов, совместимых с идеологией КПК. Результатом этой работы становятся различные публикации и руководства, распространяющиеся среди священников и верующих. Для протестантов таким примером служит попытка ослабить традиционную доктрину «оправдания верой», что должно привести к примату партийно-государственной власти над религиозными авторитетами. Для мусульманской общины и общины буддистов Тибета вмешательство КПК в религиозную деятельность выражается в составлении религиозных текстов и их принудительном распространении имамами и буддистскими монахами.

Различные формы «патриотического перевоспитания» являются неотъемлемой частью подготовки религиозных лидеров государством в процессе предоставления разрешений на паломничество или поездки за границу, получения государственных должностей или финансирования. В некоторых районах Синьцзяна мусульмане, которые хотят получать пособия по социальному обеспечению или сохранить государственную должность, должны подписывать обещания не соблюдать Рамадан. Лидеры католиков вынуждены принимать участие в церемониях, которые возглавляли епископы, не назначенные папой. Вмешательство партии в религиозную сферу, вероятно, будет только набирать интенсивность в 
ближайшие годы, поскольку Си Цзиньпин поставил задачу «китаизации» религии с иностранными корнями, что подразумевает вмешательство в религиозную деятельность всех конфессий [Cook 2017: 11].

Религиозная политика Коммунистической партии Китая в период правления Си Цзиньпина обрела ряд специфических характеристик, которые составляют определенное противоречие. На официальном уровне свобода вероисповедания граждан Китая закреплена в Конституции, а также подтверждается рядом законодательных актов и партийных документов. Однако в курсе вероисповедальной политики партии все яснее обозначается выдвижение одних конфессий на первый план на фоне притеснения других. Так, буддизм, конфуцианство и даосизм постепенно переносятся в поле культурного наследия Поднебесной и применяются в рамках продвижения «мягкой силы» культуры. В то же время представители мусульманской, христианской общин и сангхи буддистов Тибета подвергаются очевидной дискриминации, выраженной в постоянном контроле партийно-государственных органов за религиозной практикой, навязывании изменений на доктринальном уровне и т.д.

Статья выполнена в рамках проекта Российского научного фонда 14-18-00444 «Буддизм в социально-политических и культурных процессах России, Внутренней и Восточной Азии: трансформации и перспективы».

\section{Список литературы}

Нагуслаева Е.А. 2017. Буддийская дипломатия в отношениях Китая, Японии и Республики Корея. - Грамота (Тамбов). № 12(86). Ч. 5. С. 165-171.

Bell A.S. 2016. Revisionist Religion Xi Jinping's Suppression of Christianity and Elevation of Traditional Culture as Part of a Revisionist Power Agenda. - Georgetown Journal of Asian Affairs. No 3. P. 67-93.

Cook S. 2017. The Battle for China's Spirit. Religious Revival, Repression, and Resistance under Xi Jinping. - Freedom House. URL: https://freedomhouse.org/ sites/default/files/FH_ChinasSprit2016_FULL_FINAL_140pages_compressed.pdf (accessed 15.11.2018).

Fenggang Yang. 2004. Between Secularist Ideology and Desecularizing Reality: The Birth and Growth of Religious Research in Communist China. - Sociology of Religion. Vol. 65. No. 2. P. 101-119.

$\mathrm{Fu}$ B. 2015. Religious Freedom, Human Rights, and Rule of Law Deteriorating Rapidly in China. The Congressional-Executive Commission of China. Доступ: https://www.cecc.gov/sites/chinacommission.house.gov/files/CECC\%20 Hearing\%20-\%20Religious\%20Freedom\%20-\%2023July15\%20-\%20Bob\%20Fu.pdf (accessed 15.11.2018).

Global Religious Landscape. - Pew Research Center's Forum on Religion \& Public Life. URL: http://www.pewforum.org/2012/12/18/global-religious-landscape-exec/ (accessed 15.11.2018).

Hongyi Harry Lai. 2003. The Religious Revival in China. - The Copenhagen Journal of Asian Studies. Vol. 18. P. 40-46.

Zheng Wang. 2014. The Chinese Dream: Concept and Context. - Journal of Chinese Political Science. Vol. 19. No. 1. P. 1-13.

杨凯乐. 2016. 《宗教事务条例修订草案 (送审稿)》评论 [Комментарии к проекту поправок «Правил регулирования по делам религии»]. Pu Shi Institute for Social Science. Доступ: http://www.pacilution.com/ShowArticle.asp?ArticleID=7178 (проверено 15.11.2018). 
NAGUSLAEVA Elizaveta Al'bertovna, master's student at the Institute of Asian and African Studies, Lomonosov Moscow State University (11 Mokhovaya St, Moscow, Russia, 125009; nageliz@icloud.com)

\section{JINPING'S RELIGIOUS POLICY}

Abstract. The article is devoted to the study of the religious policy of the Communist Party of China during the rule of Xi Jinping from 2013 to the present day. The author names changes in the religious policy course under the current government and its specific characteristics. The article also describes the practical application of state installations in relation to religion on the example of particular confessions. The author makes a conclusion about the inconsistency in the religious policy pursued by the authorities.

Keywords: religious policy, CPC, China, Xi Jinping 